\title{
Current Approach to Hyperbaric Oxygen Therapy
}

\section{Hiperbarik Oksijen Tedavisinde Güncel Yaklașım}

(D) Füsun Kocaman Ürütük
Sişli Florence Nightingale Hospital, Hyperbaric Oxygen Therapy Center, Is
ABSTRACT
Hyperbaric oxygen (HBO) therapy is a therapy method based on
inhalation of $100 \%$ pure oxygen through a mask or endotracheal
tube or directly from the environment while subjected to
a fully closed pressure chamber with >1 atmosphere. It has
been successfully used to treat many diseases from different
medical specialties. This review, apart from describing the
general features of HBO therapy, emphasises on its therapeutic
application in different medical specialties. This would
promote its usage, alongside other methods, by physicians
from different clinical fields.
Keywords: Hyperbaric oxygen, decompression illness, carbon
monoxide, diabetic foot, vascular disease, osteomyelitis,
post-operative wounds, crush, grafts flaps, filling injection
complications, radionecrosis, sudden deafness, sudden
blindness

\section{ÖZ}

Hiperbarik oksijen (HBO) tedavisi, tamamen kapalı bir basınç odası içerisinde, 1 atmosferden daha yüksek basınçlarda, ortamdan, maskeyle veya endotrekeal tüp vasıtasıyla fasılalı olarak \%100 saf oksijen solutulmasına dayanan bir tedavi yöntemidir. Farklı tıp dallarından birçok hastalıkta başarı ile kullanılmaktadır. Bu derlemede, HBO tedavisinin genel özelliklerinin tanımlanması dışında, farklı olarak, branşlara göre kullanım alanlarının vurgulanması, böylece farklı kliniklerden hekimlerin bu tedavi yöntemini hastaları için kullanabilmelerine rehberlik edilmesi amaçlanmıştır.

Anahtar Kelimeler: Hiperbarik oksijen, dekompresyon hastalı̆̆ı, karbonmonoksit, diyabetik ayak, periferik vasküler hastalık, osteomiyelit, postoperatif yara, ezilme yaralanması, riskli greft flepler, dolgu komplikasyonu, radyonekroz, ani işitme kaybı, ani görme kaybı

\section{Short History}

Oxygen was first found in 1772 by Swedish chemist Carl Wilhelm. However, he himself has not reported this scientifically. In 1774, the English chemist Joseph Priestly published and introduced it in the scientific framework (1). Hyperbaric oxygen (HBO) therapy first started in France in the late $19^{\text {th }}$ and early $20^{\text {th }}$ centuries. In 1834 , Junod explained the positive effects of high pressure oxygen, and in 1876 mobile compartments were put into use. Production of hyperbaric chambers began from 1860. Paul Bert, considered the father of Hyperbaric Medicine, has described the effectiveness of HBO therapy. In the same years, Haldane reported that carbon monoxide intoxication was effectively treated with HBO therapy (1-4).

\section{Definition}

HBO therapy is a therapy based on the inhalation of 100\% pure oxygen intermittently in a completely closed pressure chamber, at pressures higher than 1 atmosphere, from ambient air, by mask or by endotrekeal tube (Figure 1-3) (5).

\section{Mechanism of Hyperbaric 0xygen Therapy}

The two main rules of HBO therapy, pressure and 100\% oxygen, also form the basis of the mechanism of effect.

\section{Effects of pressure}

\section{Effects of oxygen}

1. The effects of pressure: According to Boyle-Mariotte law, gases contract with the effect of pressure applied externally. During pressurization, also called the compression phase of HBO therapy, a contraction occurs in gas-containing cavities in the body. The air in the middle ear can be narrowed by manoeuvres such as Valsalva, Frenzel; the air in the lungs can be narrowed by breathing; and the air in the sinuses and intestines can be balanced spontaneously. With this effect, it is possible to downsizing air bubbles present in the tissue and intravascular area and reduce tissue blood pressure in diseases such as gas gangrene, air and gas embolism, and decompression sickness. The bubble, which has lost its spheric form, may disappear or be eliminated from the lungs (5-9). 
2. The effects of oxygen: According to Henry's law, under pressure, the solubility of gases in liquids increases. In HBO therapy conducted in 2.8 atmospheres, the amount of oxygen dissolved in plasma is six times the amount in normobaric conditions. The dissolved oxygen carried by the plasma can provide the amount needed for the tissue to survive, even if there is no oxygen due to hemoglobin. By this mechanism, the antimicrobial effect of leukocytes is supported, adherence of leukocytes to the capillary wall is reduced, physiological vasoconstriction occurs in normal tissues, fibroblast growth and collagen construction increase, making of superoxide dismutase is triggered, adenosine triphosphate, the cell membrane present in tissue edema, is conserved; osteoclastic activity is regulated, capillary proliferation increases, ocular lens flexibility is reduced, surfactant construction is reduced in the lungs, separation of carbon monoxide (CO) gas from hemoglobin and suppressing alpha toxin production in gas gangrene. In the case of hyperoxia, it is also possible to withdraw the edema at intersellular distance to the intravascular area while vasoconstricting and reduce the distance that dissolved oxygen must exceed to reach the tissue (5-8).

\section{Indications for Hyperbaric 0xygen Therapy}

The United States-based Undersea and Hyperbaric Medical Society (UHMS) and the European Committee for Hyperbaric Medicine (ECHM) have been working extensively on the creation of indications lists for HBO therapy. Lists of indications that can be applied according to these commissions are given in Table $1(10,11)$.

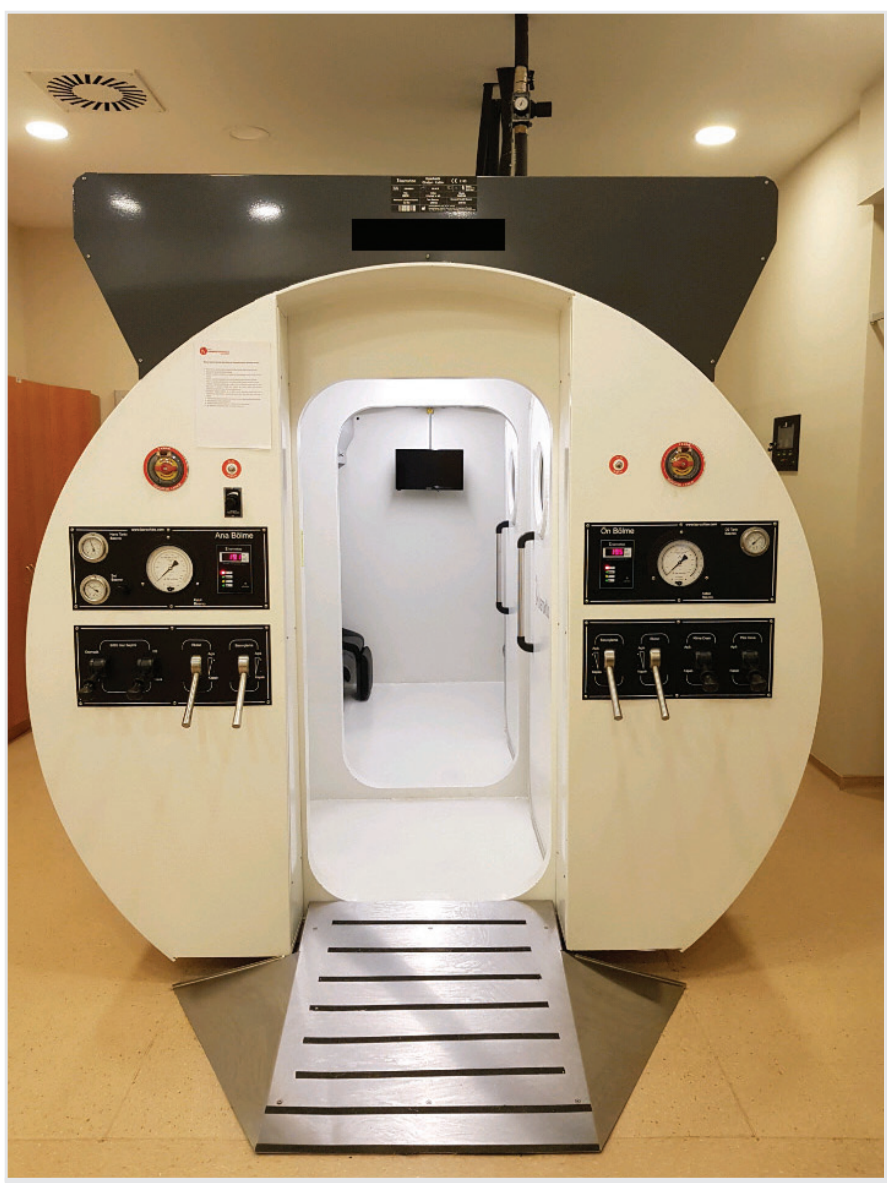

Figure 1. Multiplace pressure chamber
According to the HBO therapy application list in annex 2D-3 of the Health Implementation Comminique in our country, the indication list evaluated under the Social Security Instution of is summarized in Table 2 (12).

In addition, there are diseases that are being investigated and positive results are being reported, with extensive research expected.

\section{Emergency Medicine and Hyperbaric 0xygen Therapy}

Apart from CO poisoning and sudden vision loss, decompression sickness and air/gas embolism, which lead to the birth of undersea medicine, are diseases that emergency physicians may encounter in their emergency clinics.

Anamnesis of those suffering from decompression disease is most likely a recent history of diving or a history of exposure to high pressure and associated skin and neurological involvement. In this disease, which develops after diving accompanied by deep and missed safety stops, which are not done according to the rules, HBO therapy to be applied allows the bubbles to shrink, the edema around the bubble to

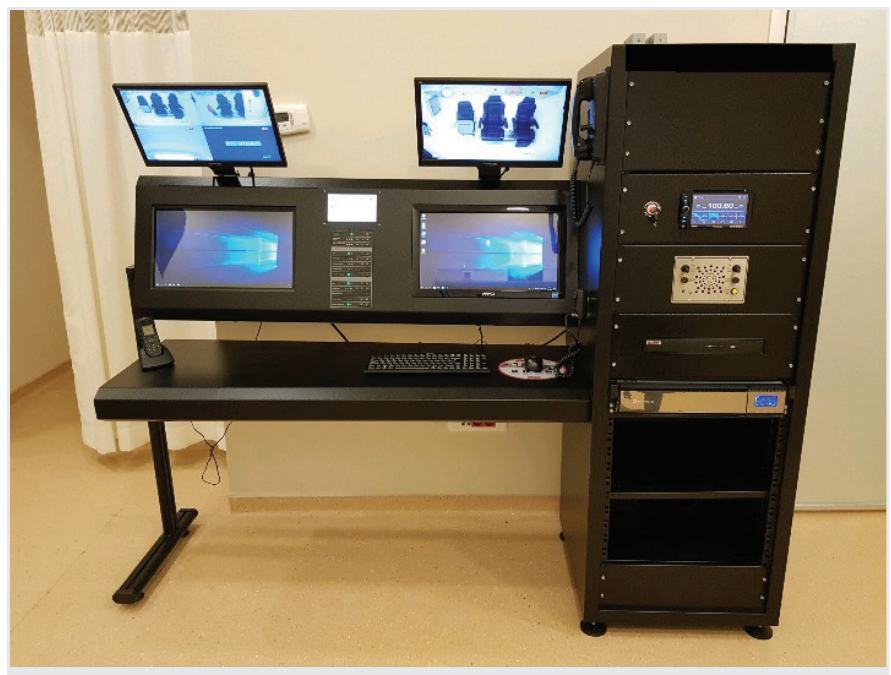

Figure 2. Control panel

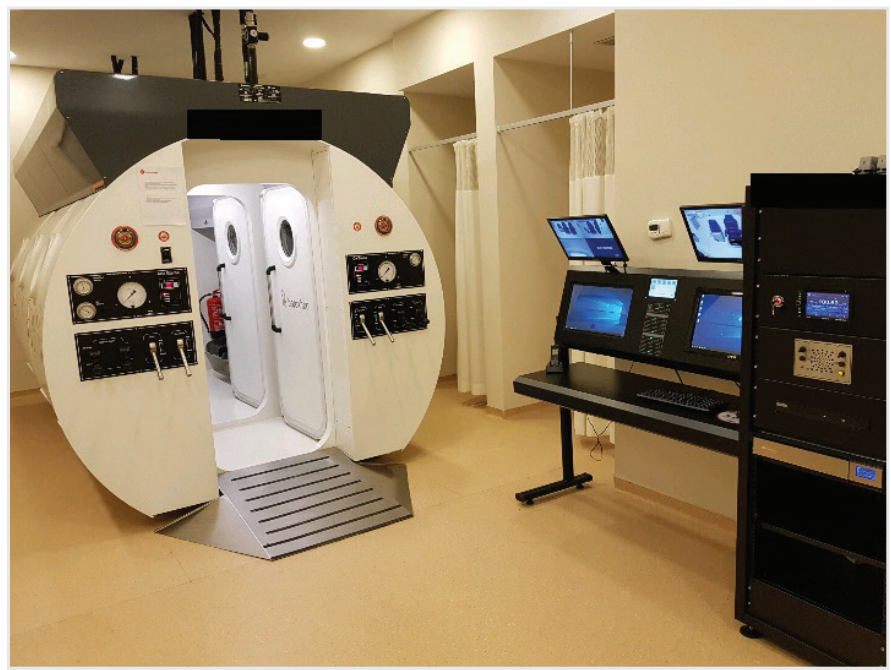

Figure 3. Hyperbaric oxygen therapy unit 


\section{Table 1. Indications for hyperbaric oxygen therapy}

\section{UHMS indications}

- Air and gas embolism

- Arteriel insufficiencies

- Carbon monoxide (CO) poisoning

- Clostridial myonecrosis

- Compromised grafts and flaps

- Acute traumatic ischemia

- Decompression sickness

- Radiation injury

- Idiopathic sudden sensorineural hearing loss

- Necrotizing soft tissue infections

- Refractory osteomyelitis

- Severe anemia

- Thermal burns
- Intracranial abscess

\section{ECHM indications}

\section{Absolute Indications}

- CO poisoning

- Open fractures with crush injury

- Prevention of osteoradionecrosis after dental extraction

- Mandible osteoradionecrosis

- Soft tissue radionecrosis (cystitis, proctitis)

- Decompression illness

- Gas embolism

- Anaerobic and mixed bacterial infections

- Sudden deafness

\section{General Indications}

- Diabetic foot lesions

- Femoral head avascular necrosis

- Compromised skin grafts and musculocutaneous flaps

- Central retinal artery occlusion

- Crush Injury without fracture

- Osteoradionecrosis (bones other than mandible)

- Soft tissue radionecrosis other than cystitis and proctitis

- Application of preoperative or preimplant protection to radiotherapytreated tissue

- Ischaemic ulsers

- Refractory chronic osteomyelitis

- $2^{\text {nd }}$ degree more than $20 \%$ body surface area

- Pneumatosis cystoides intestinalis

- Neuroblastoma stage IV

\section{Relative Indications}

- Selected cases in acute and chronic brain trauma, chronic stroke, postanoxic encephalopathy

- Radio-induced lesions of larynx

- Radio-induced lesions of the central nervous system

- Reperfusion syndrome

- Limb replantation

- Selected non-healing wounds secondary to systemic processes

- Sickle cell disease

- Interstitial cystitis
UHMS: Undersea and Hyperbaric Medical Society, ECHM: Europen Committee for Hyperbaric Medicine

\section{Table 2. Social security institution hyperbaric oxygen therapy} indication list

\begin{tabular}{l} 
Decompresson sickness \\
Air embolism \\
CO poisoning and toxic effect of gases and cyanides \\
Gas gangrene \\
Soft tissue infections, fasciitis, necrotizing fasciitis \\
Crush, compression, post-traumatic Injuries \\
Diabetic foot wounds and infections \\
Peripheral vascular disease, vascular-induced ulcers such as Buerger's \\
disease, infections, and wounds that develop after thromboembolism \\
Venous ulcers \\
Chronic ulcers \\
Decubitus ulcers \\
Postoperative wound, infection, vascular complications \\
Spondylodiscitis, intervertebral disc infection: acute, subacute, chronic \\
osteomyelitis \\
Prosthetic infection and inflammation \\
Avascular necrosis \\
Late effects of cystitis, dermatitis, proctitis and other radiation due to RT \\
After graft and flap operations \\
Burns \\
Frostbite \\
Intracranial abscess \\
Anoxic encephalopathy \\
Malign otitis externa \\
Sudden sensorineural hearing loss \\
Retinal artery occlusions \\
RT: Radiotherapy, CO: Carbon monoxide \\
\hline
\end{tabular}

decrease and the inflammation to be reduced. The patient's skin and neurological signs are reduced, especially when the blisters shrink. It should be remembered that the only treatment for decompression disease is the HBO therapy, and that it should be seen by an undersea medicine physician even if there is a claim that safe diving is performed in the story $(2,8,13-16)$.

Air gas embolism is the condition of gas bubbles in the vascular area. This condition may be iatrogenic after some surgical intervention or invasive procedures, or may develop after lung barotrauma in diving or other hyperbaric environments. This disease can result in Aacute respiratory distress syndrome, brain edema, lack of brain metabolism, and sudden death. In non-fatal cases, air bubbles block circulation; it can be seen that hemoconcentration develops when platelets, leukocytes, fibrinogen and thrombin adhere to the bubble, and the clinical picture is rapidly aggravated. In the following period, the thrombotic process comes to the fore and deterioration occurs in the vessel wall. This disease can be an unintended complication of diving, surgical practice and undersea medicine practice. As soon as the clinical picture is recognized, the bubbles in the vascular site of the patient receiving HBO therapy shrink, the nitrogen load in the bubble is reduced, the activation of the 
adhesion cascade decreases, hypoxia of ischemic tissue regresses, and brain edema decreases. HBO therapy can be applied to the patient who needs intensive care support until the clinical picture declines (2,17-20).

\section{Internal Medicine and Hyperbaric 0xygen Therapy}

In our country, the incidence of CO poisoning caused by coal and wood stove is high, especially in winter. CO binds to hemoglobin due to its high affinity as a gas, creating hypoxia within the cell at the mitochondrial level. It has been proven that this causes ultrastructural changes in myocytes and swells in mitochondria in electron microscopic investigations of the myocardial, and this is due to deterioration of the energy use of the myocardial $(21,22)$. HBO therapy speeds up the separation of CO gas from hemoglobin, shortening the time it takes to be excreted from the body and correcting intracellular hypoxia. In the studies, it was determined that damage due to CO intoxication in the myocardium was also improved with HBO therapy $(23,24)$.

In patients diagnosed with CO intoxication in the emergency department,

- co level over 25\%,

- Co level over $20 \%$ and pregnant,

- Loss of consciousness and/or in the presence of pathological neurological signs,

- In the presence of end organ damage such as ischemic findings in electrocardiogram,

- In severe metabolic acidosis.

HBO therapy should be used to reduce mortality and increase cure rate (24-29). It should be kept in mind that intracellular hypoxia can persist even if the CO level in blood gas decreases, and that myocardial damage and clinical signs may be seen even in patients below the levels mentioned above (22).

\section{General Surgery and Hyperbaric 0xygen Therapy}

Surgical interventions, for whatever purpose, disrupt the integrity of the body and create a controlled and clean wound on the skin. In normal wound healing;

$-1^{\text {st }}$ day hemostasis,

- 0-3 day inflammatory phase,

$-3-15^{\text {th }}$ day remodelization phase

occurs and the process continues. The wound healing stops due to an intrinsic or extrinsic problem occurring in one or more of these processes and the clinical picture of the postoperative wound appears. Infection and ischemia are the most common causes of wound healing delay (2). The infection causes an exaggerated response in the inflammatory phase of wound healing, resulting in rapid depletion of oxygen in the tissue, resulting in insufficient blood flow due to the effect of tissue edema. However, ischemia occurs because the tissue reaches less oxygen than it needs. The wound location is hypoxic, hypoglycemic, acidotic, hyperkalemic, hyperlactic, and hypercarbic due to these reasons. Especially, fibroblast proliferation, Iysine and proline hydroxylation in collagen synthesis, angiogenesis, and leukocytosis activity are oxygen- dependent functions. This whole healing process is interrupted by lack of oxygen (2,30-32).

Diabetic foof ulcer develops in $2.2 \%$ of diabetic patients every year and training for prevention of ulcer provides serious benefits to the national economy (33). Diabetic patients account for a significant proportion of non-traumatic amputations and morbidity all over the world. In diabetic foot treatment with multidisciplinary approach, good regulation of diabetes, proper dietary protocol, control of infection, correction of vascular pathologies, adequate and timely debritmans, daily optimal wound healing environment, reducing pressure on the foot area and HBO therapy should be added to the protocol. Educating the patient about diabetic foot and explaining the importance of following medical treatment and diet program will reduce recurrence in amputations of foot ulcers, and the addition of HBO therapy will decrease the amputation rate (34-38). Such publications can be seen as an indication that attention needs to be paid to patient selection and the time at which the patient is referred to an HBO therapy clinic.

The main reason behind all non-healing wounds, postoperative wounds, soft tissue infections and diabetic foot wounds are lack of oxygen and the problem in wound healing processes. HBO therapy attempts to restore healthy functioning of this process by providing the oxygen that tissue needs, reducing edema, controlling infections, regulating intracellular metabolism, and increasing the effectiveness of antibiotics. In recent years, the use of perioperative HBO therapy has also started to be suggested by publications $(39,40)$. It is important to recognize the patient at risk during the preoperative period, to identify early complications in the wound healing process during the postoperative period and to take the necessary precautions.

In addition to surgical, nephrological and intensive care support, HBO therapy can also be applied in severe energy traumas, earthquake, traffic accident, industrial accident, crush injuries, compartment syndrome, risky flap/graft and organ replantation. The main pathology in all of these diseases is ischemia and tissue edema. While the increase of edema causes vicious circle by increasing hypoxia in the tissue, reduction of edema, supply of needed oxygen to the tissue, re-provision of microcirculation, elimination of hypoxia and breaking of the cycle can be achieved with HBO therapy. Unlike normobaric oxygen, HBO therapy can enhance tissue viability and reduce the need for amputation by increasing the amount of dissolved oxygen in the plasma, reducing the need for operations, shortening the duration of hospitalization and preventing the risk of hospital infection (41-44).

\section{Plastic Surgery and Hyperbaric Oxygen Therapy}

In addition to diabetic foot wounds, postoperative wounds, compromised grafts/flaps, organ replantation, HBO therapy can also be useful in the prevention and relief of complications of medical aesthetic applications $(2,40,44-47)$.

In risky grafts and flaps, HBO therapy supports preoperative site preparation, control of infections, reduction of graft/flap edema during postoperative period, increase of collagen production and reduction of rejection (44-46). 
Successful HBO therapy practices have been reported following replantations of tissue losses such as ear amputation and penile amputation. The replanted tissue continues to be fed with dissolved oxygen from microcirculation and merges with healthy tissue $(47,48)$.

After filling applications to replace the tissue loss on the face caused by aging, sudden vision loss and tissue necrosis may develop and HBO therapy may be applied to these types of cases. HBO therapy reduces edema in the filling area, is useful in correcting hypoxia and reduces scar formation $(48,49)$.

\section{Orthopedics and Hyperbaric Oxygen Therapy}

Indications of HBO therapy in orthopedics can be summarized as postoperative wound healing, osteomyelitis and avascular necrosis.

Osteomyelitis is a pyogenic infection of the bone that can be difficult to treat, progressive and recurrent. Hypoxia, ischemia and necrosis develop in the bone due to infection. Furthermore, the strong structure of the bone causes the infection to be controlled and the effectiveness of the antibiotic therapy to decrease in bone tissue (50). Surgery, antibiotics sensitive to bone culture and HBO therapy are applied in the treatment. From the point of view of Hyperbaric Medicine, whatever the cause, this is a kind of closed wound and local oxygen support is important in correcting hypoxia in the tissue, controlling the infection and in remission of the disease. HBO therapy removes hypoxia by correcting edema and microcirculation, increases bactericidal activity of neutrophils with increased oxygen in tissue, increases vascularization, allows antibiotics to be transported and penetrated to the problem area, and accelerates postoperative wound healing (50-52).

Etiopathogenesis of avascular necrosis includes corticosteroids, alcohol, infections, dysbaric conditions, infiltrating diseases of the bone marrow, coagulation defects, autoimmune diseases. Basically, it is a bone disease which is associated with tissue edema due to decreased local blood circulation, which leads to necrosis in the bone and creates the need for prosthetics in the later stages (53-55). In addition to bone drill operation, HBO therapy also has the effect of reducing existing hypoxia and edema, improving metabolism in bone tissue and regulating osteoclastic and blastic activity, enabling bone tissue regeneration (54,56-59).

In orthopedics, HBO therapy can also be used for perioperative and postoperative wound healing $(39,40)$.

\section{Vascular Surgery and Hyperbaric Oxygen Therapy}

Wounds related to peripheral artery disease accompanied or not by diabetes, venous ulcers and sternum osteomyelitis following cardiac surgery are groups of patients that vascular surgeons and undersea physicians can follow together. In cases where oxygen transport is restricted due to mechanical reasons, such as peripheral artery disease and Buerger's disease, even if the gold standard treatment is surgical, HBO therapy carries oxygen needed for tissue regeneration, dissolved in plasma, and provides major factors for wound healing. In addition, reduction of carbon dioxide retention and residual substances will reduce claudication and decrease the limitation of the patient's ability to activity (37,60-63). Because of this effect, it is possible to stop the deterioration of the tissue and wound during the preoperative period and to recover faster both the existing wound and the operation wound during the postoperative period.

In ulcers that develop due to venous insufficiency, surgical intervention, restriction of patient standing time, elastic bandages, appropriate varicose veins, as well as the application of HBO therapy will accelerate wound healing. HBO therapy plays an active role in reducing local edema, in the development of granulation tissue in the wound, and in accelerating epithelization, and provides wound healing $(2,31,63)$.

In addition to the treatment of sternal infections and osteomyelitis that develop after cardiothoracic surgery, HBO therapy can be used. HBO therapy with its effects such as reduction of hypoxia, reduction of edema, support of immune resistance of the patient, increase of antibiotic effectiveness, reduces the duration of antibiotic therapy in this disease and reduces relapses (64-67).

\section{Radiation Oncology and Hyperbaric 0xygen Therapy}

While in radiotherapy (RT) the target is cancerous tissue, neighboring normal tissue is also damaged and suffers loss of healthy cells and capillary vessels. In tissue that has lost its cells and blood supply, fibrosis develops accompanied by hypoxia. The tissue in this condition has problems in healing due to a surgical intervention, trauma or a spontaneous wound. Osteonecrosis of the jaw after RT applied in head and neck cancers, radiation cystitis after RT applied in genital region cancers, proctitis can be given as an example of these diseases. HBO therapy removes hypoxia in the tissue in these diseases, speeding up new cell construction, collagen production and angiogenesis/ neovascularization (2,68-72). According to the Marx protocol, giving HBO therapy prior to surgery, such as tooth extraction, especially to the patient who has received RT due to head and neck cancer provides protection from osteoradionecrosis (69).

\section{Eye Diseases and Hyperbaric 0xygen Therapy}

Retinal artery occlusion is one of the emergency indications by both ophthalmologists and undersea physicians. It is characterized by sudden blindness that develops immediately following occlusion of the retinal artery and its branches due to reasons such as thrombus, embolism, vasculitis. The aim should be to reduce or dissolve the thrombus/ embolism, to restore circulation and to provide tissue nutrition with the help of collaterals or diffusion until this is achieved. Retinal cells are very sensitive to hypoxia. Therefore HBO therapy should be administered very quickly in such cases $(2,73,74)$.

\section{Otolaryngology and Hyperbaric 0xygen Therapy}

Sudden hearing loss, malignant otitis externa and postoperative wound healing are indications that otolaryngology will be supported by undersea physicians.

Sudden hearing loss is defined as greater than 30 decibels sensorineural hearing reduction, over at least three contiguous frequencies, occurring over 3 days or less (75). In etiology, vascular causes, viral cochleitis, autoimmune diseases and acoustic trauma can be considered. The common feature of all these causes is hypoxia in the inner ear $(75,76)$. HBO therapy, which is added to steroid therapy, corrects hypoxia in 
Füsun Kocaman Ürütük. Current Approach in Hyperbaric Oxygen Therapy

the inner ear, reduces edema, reactivates cells whose metabolism has stopped, and restores hearing (2,75-77).

Otitis externa is a life-threatening, progressive infection of the soft tissue of the external ear canal. Patients may have diseases such as diabetes, immunosuppressive use, or cancer. HBO therapy, when added to appropriate antibiotics, regresses edema in the outer ear tract, increases the effectiveness of antibiotics, strengthens body defense mechanisms, provides remission of osteomyelitis in bone tissue. HBO therapy should be considered as an adjuvant therapy pathway, especially in resistant cases $(78,79)$.

\section{Neurosurgery and Hyperbaric 0xygen Therapy}

Spondylodiscitis and intracranial abscesses are in neurosurgical indications where HBO therapy is used.

Intracranial abscesses are formed by aerobic and anaerobic agents in the brain tissue. HBO therapy reduces edema around the abscess, acts bactericidal to anaerobic microorganisms inside the abscess, reduces hypoxia, increases antibiotic penetration, strengthens body defense mechanisms and helps control the infection in the abscess. HBO therapy may be useful, especially if any of these parameters are present $(51,80,81)$ :

\section{- Multiple abscesses,}

- Deep and large abscess,

- Early stage abscess that does not require surgery,

- High-risk patient profile,

- Non-surgical, risky abscess,

- Anaerobic or multiple bacterial isolation,

- Failure to respond to standard treatment.

As a result, HBO therapy is a treatment that has hyperoxic, edema-reducing, infection-fighting, immune system-supporting, neovascularization-enhancing, inflammation-reducing, wound healingaccelerating effects. In the light of scientific studies, a new effect is emerging every day and the list of diseases it can treat is expanding. With the new data to be added to the literature in the coming years, it can be seen that this branch of science is very open to development and progress, and in its current form it can take place in the treatment protocols of many diseases from different clinics.

\section{Ethics}

Peer-review: Internally peer-reviewed.

Financial Disclosure: The author declared that this study received no financial support.

\section{References}

1. Clarke D. History of hyperbaric therapy. Neuman T, Thom S, editors. Physiology and Medicine of Hyperbaric Oxygen Therapy. Philadelphia: Saunders Elsevier; 2008.p.3-23.

2. Çimşit M. Hiperbarik Tıp. İstanbul-Türkiye: Efil Yayınevi; 2009

3. Wattel F. A history of hyperbaric medicine. Mathieu D, editor. Handbook on Hyperbaric Medicine. Dordrecht: Springer; 2006.p.1-11.
4. Kindwall EP. Hyperbaric oxygenation - general considerations- A history of hyperbaric medicine. Kindwall EP, editor. Hyperbaric Medicine Practice. Arizona: Best Publishing Company; 1995.p.1-16.

5. Hardy K. The physics of hyperbaric oxygen therapy. Neuman TS, Thom SR, editors. Physiology and Medicine of Hyperbaric Oxygen Therapy. Philadelphia: Saunders Elsevier; 2008.p.57-64.

6. Welslau W. Physics of hyperbaric pressure. Mathieu D, editor. Handbook on Hyperbaric Medicine. Dordrecht: Springer; 2006.p.15-24.

7. Hammarlund C. Hyperbaric oxygenation - general considerations- The physiologic effects of hyperbaric oxygen. Kindwall EP, editor. Hyperbaric Medicine Practice. Arizona: Best Publishing Company; 1995.p.17-32.

8. Welslau W. Physiologic effects of increased barometric pressure. Mathieu D, editor. Handbook on Hyperbaric Medicine. Dordrecht: Springer International Publishing; 2006.p.31-48

9. Ratzenhofer-Komenda B, Fovory R, Welslau W, Somlle-Jüttner FM, Mathieu D. Physiologic effects of hyperbaric oxygen transport and tissue oxygen pressure. Mathieu D, editor. Handbook on Hyperbaric Medicine. Dordrecht: Springer International Publishing; 2006.p.49-74.

10. UHMS. Moon RE, editor. Hyperbaric Oxygen Therapy Indications 14th Edition. Best Publishing Company; 2019.

11. Mathieu D, Marroni A, Kot J. Consensus Conference. Diving and Hyperbaric Medicine 2017; 47: 24-32.

12. Sağlık Uygulama Tebliği. 05.07.2018 tarih ve 30469 Mükerrer Sayılı Resmi Gazete. Ek 2-D-3, 2013. Available from URL: https://www.resmigazete.gov.tr/ eskiler/2018/07/20180705M1-1.htm

13. Elliott DH. Disorders approved for treatment with hyperbaric oxygen, Decompression sickness. Kindwall EP, editor. Hyperbaric Medicine Practice. Arizona: Best Publishing Company; 1995.p.311-26.

14. Moon RE, Gorman DF. Decompression sickness. Neuman TS, Thom SR, editors Physiology and Medicine of Hyperbaric Oxygen Therapy. Philadelphia: Saunders Elsevier; 2008.p.283-320.

15. Marroni A, Cronje FJ, Meintjes J, Cali-Corleo R. Dysbaric Illness. Mathieu D, editor. Handbook on Hyperbaric Medicine. Dordrecht: Springer International Publishing; 2006.p.173-216.

16. Vann RD, Butler FK, Mitchell SJ, Moon RE. Decompression illness. Lancet 2011; 377: 153-64.

17. Hoesen KV, Neuman TS. Gas embolism venous and arterial gas embolism. Neuman TS, Thom SR, editors. Physiology and Medicine of Hyperbaric Oxygen Therapy. Philadelphia: Saunders Elsevier; 2008.p.257-81.

18. Mathieu D, Tissier S, Boulo ML. Gas embolism. Mathieu D, editor. Handbook on Hyperbaric Medicine. Dordrecht: Springer International Publishing; 2006.p.217-38

19. Kindwall EP. Disorders approved for treatment with hyperbaric oxygen- Gas embolism. Kindwall EP, editor. Hyperbaric Medicine Practice. Arizona: Best Publishing Company; 1995.p.327-42.

20. Malik N, Claus PL, Illman JE, Klingerman SJ, Moynagh MR, Levin DL, et al. Air embolism: diagnosis and management. Future Cardiol 2017; 13: 365-78.

21. Tritapepe L, Macchiarelli G, Rocco M, Scopinaro F, Schiallaci O, Mastuscelli E, et al. Functional and ultrastructural evidence of myocardial stunning after acute carbon monoxide poisoning. Crit Care Med 1998; 26: 797-801.

22. Song L, Bian G, Yang W, Li HF. Variant angina induced by carbon monoxide poisining. Medicine (Baltimore) 2019; 98: 16.

23. Satran D, Henry CR, Adkinson C, Nicholson Cl, Bracha Y, Henry TD Cardiovascular manifestations of moderate to severe carbon monoxide poisining. J Am Coll Cardiol 2005; 45: 1513-6. 
24. Mathiue D, Mathieu-Nolf M, Linke JC, Favory R, Wattel F. Carbon monoxide poisining. Mathieu D, editor. Handbook on Hyperbaric Medicine. Dordrecht: Springer International Publishing; 2006.p.239-62.

25. Weaver LK. Carbon monoxide poisoning. Crit Care Clin 1999; 15: 297-317.

26. Kao LW, Nañagas KA. Carbon monoxide poisoning. Emerg Med Clin North Am 2004; 22: 985-1018.

27. Hampson NB, Dunford RG, Kramer CC, Norkool DM. Selection criteria utilized for hyperbaric oxygen treatment of carbon monoxide poisoning. J Emerg Med 1995; 13: 227-31.

28. Huang CC, Ho CH, Chen YC, Lin HJ, Hsu CC, Wang JJ, et al. Hyperbaric oxygen therapy is associated with lower short- and long-term mortality in patients with carbon monoxide poisoning. Chest 2017; 152: 943-53.

29. Eichcorn L, Thudium M, Jüttner B. The diagnosis and treatment of carbon monoxide poisining. Dtsch Arztebl Int 2018; 115: 863-70.

30. Knighton DR. Mechanisms of wound healing. Kindwall EP, editor. Hyperbaric Medicine Practice. Arizona: Best Publishing Company; 1995.p.119-40.

31. Jain KK. HBO therapy in wound healing, plastic surgery, and dermatology. Kain JJ, editor. Textboof of Hyperbaric Medicine Sixth Ed. Cham: Springer International Publishing 2017.p.183-206.

32. Tapias LF, Wright CD, Lanuti M, Muniappan A, Deschler D, Mathisen DJ. Hyperbaric oxygen in the prevention and management of tracheal and oesophageal anastomotic complications. Eur J Cardiothorac Surg 2020; 57: 1203-9.

33. Ramsey SD, Newton K, Blough D, McCulloch DK, Sandhu N, Reiber GE, et al. Incidence, outcomes, and cost of foot ulcers in patients with diabetes. Diabetes Care 1999; 22: 382-7.

34. Eleftheriadou I, Kokkinos A, Liatis S, Makrilakis K, Tentolouris N, Tentolouris A, et al. Atlas of the Diabetic Foot. Third ed. New Jersey: Wiley Blackwell, 2019.

35. Boulton AJ, Armstrong DG, Albert SF, Frykberg RG, Hellman R, Kirkman MS, et al. American Diabetes Association; America Association of Clinical Endocrinologists. Comprehensive foot examination and risk assessment: a report of the task force of the foot care interest group of American Diabetes Association, with endorsement by the American Association of Clinical Endocrinologist. Diabetes Care 2008; 31: 1679-85.

36. Kaya A, Aydin F, Altay T, Karapinar Levent, Ozturk Hasan, Karakuzu Cengiz. Can major amputation rates be decreased in diabetic foot ulcers with hyperbaric oxygen therapy? Int Orthop 2009; 33: 441-6.

37. Goldman RJ. Hyperbaric oxygen therapy for wound healing and limb salvage: a systematic review. PM R 2009; 1: 471-89.

38. Liu R, Li L, Yang M, Boden G, Yang G. Systematic review of the effectiveness of hyperbaric oxygenation therapy in the management of chronic diabetic foot ulcers. Mayo Clin Proc 2013; 88: 166-75.

39. Boet S, Martin L, Cheng-Boivin O, Etherington N, Louge P, Pignel R, et al. Can preventive hyperbaric oxygen therapy optimise surgical outcome?: A systematic review of randomised controlled trials. Eur J Anaesthesiol 2020; 37: 1-13.

40. Friedman T, Menashe S, Landau G, Sherf M, Wiser I, Seligman Y, et al. Hyperbaric oxygen preconditioning can reduce postabdominoplasty complications: a retrospective cohort study. Plast Reconstr Surg Glob Open 2019; 7: e2417.

41. Torp KD, Murphy-Lavoie HM. Acute traumatic ischemia hyperbaric evaluation and treatment. In: StatPearls. Treasure Island (FL): StatPearls Publishing; 2020.

42. Garcia-Covarrubias L, McSwain NE Jr, Van Meter K, Bell RM. Adjuvant hyperbaric oxygen therapy in the management of crush injury and traumatic ischemia: an evidence-based approach. Am Surg 2005; 71: 144-51.
43. Jain KK. Hyperbaric oxygenation in traumatology and orthopedics. Kain JJ, editor. Textboof of Hyperbaric Medicine. 6th ed. Cham: Springer International Publishing 2017.p.429-42.

44. Mesimeris TA. Comprimised skin graft and falp. Mathieu D, editor. Handbook on Hyperbaric Medicine. Dordrecht: Springer International Publishing; 2006.p.329-62.

45. Nemiroff PM. Disorders approved for treatment with hyperbaric oxygen, Hyperbaric oxygen in skin grafts and flaps. Kindwall EP, editor. Hyperbaric Medicine Practice. Arizona: Best Publishing Company; 1995.p.565-80.

46. Zamboni WA, Baynosa RC. Comprimised grafts and flaps. Neuman TS, Thom SR, editors. Physiology and Medicine of Hyperbaric Oxygen Therapy. Philadelphia: Saunders Elsevier; 2008.p.373-96.

47. Shapell HW, Kislevitz M, Reddy G, Amirlak B, Morey A. Successful replantation of amputated penis with adjuvant hyperbaric oxygen therapy. Undersea Hyperb Med 2019; 46: 695-9.

48. Mass CS. Complications in the cosmetic Office setting. Complications in facial plastic surgery. Capone RB, Sykes JM, editors. New York: Thieme Medical Publishers Inc 2012.p.10-6.

49. Hwang K. Hyperbaric oxygen therapy to avoid blindless from filler injection. J Craniofac Surg 2016; 27: 2154-5.

50. Kemmer A, Stein T, Heirholzer C. Persistent osteomyelitis. Mathieu D, editor Handbook on Hyperbaric Medicine. Dordrecht: Springer International Publishing; 2006.p.429-50.

51. Britt MW, Calhoun J, Mader JT, Mader JP. Disorders approved for treatment with hyperbaric oxygen- The use of hyperbaric oxygen in the treatment of osteomyelitis. Kindwall EP, editor. Hyperbaric Medicine Practice. Arizona: Best Publishing Company; 1995.p.419-28.

52. Kirby JP. Hyperbaric oxygen therapy as an elective treatment. Mo Med 2019; 116: $184-7$

53. Ditri L, Montanari Y, Melamed Y, Reis D. Femoral head necrosis. Mathieu D, editor. Handbook on Hyperbaric Medicine. Dordrecht: Springer International Publishing; 2006.p.547-52.

54. Assouline-Dayan Y, Chang C, Greenspan A, Shoenfeld Y, Gershwin ME. Pathogenesis and natural history of osteonecrosis. Semin Arthritis Rheum 2002; 32: 94-124.

55. Shier A, Abdelrazek M, Soliman A, De Sanctis V, Elsayed A, Abdulla M, et al. Short-term outcome and MRI changes in three adult patients with sickle cell disease and aseptic osteonecrosis after treatment with hyperbaric oxygen threrapy: a preliminary report. Case Rep Oncol 2020; 13: 365-72.

56. Bosco G, Vezzani G, Mrakic Sposta S, Rizzato A, Enten G, Abou-Samra A, et al. Hyperbaric oxygen therapy ameliorates osteonecrosis in patients by modulating inflammation and oxidative stress. J Enzyme Inhib Med Chem 2018; 33: 1501-5.

57. Ververidis AN, Paraskevopoulos K, Keskinis A, Ververidis NA, Molla Moustafa $\mathrm{R}$, Tilkeridis K. Bone marrow edema syndrome/transient osteoporosis of the hip joint and management with the utilization of hyperbaric oxygen therapy. J Orthop 2020; 22: 29-32.

58. Baig SA, Baig MN. Osteonecrosis of the femoral head: etiology, investigations, and management. Cureus 2018; 10: e3171.

59. Li W, Ye Z, Wang W, Wang K, Li L, Zhao D. Clinical effect of hyperbaric oxygen therapy in the treatment of femoral head necrosis: a systematic review and meta-analysis. Orthopade 2017; 46: 440-6.

60. Nakamura H, Makiguchi T, Atomura D, Yamatsu Y, Shirabe K, Yokoo S Changes in skin perfusion pressure after hyperbaric oxygen therapy following revascularization in patients with critical limb ischemia: a preliminary study. Int J low Extrem Wounds 2020; 19: 57-62. 
61. Conte MS, Bradbury AW, Kohl P, White JV, Dick F, Fitridge R, et al. Global vascular guidelines on the management of chronic limb-threatening ischemia. Eur J Vasc Endovasc Surg 2019; 58: 1-109.

62. Heyboer M, Grant WD, Byrne J, Pons P, Morgan M, Igbal B, et al. Hyperbaric oxygen for the treatment of nonhealing arterial insufficiency ulcers. Wound Repair and Regen 2014; 22: 351-5.

63. Roeckl-Wiedmann I, Bennett M, Kranke P. Systematic review of hyperbaric oxygen in the management of chronic wounds. British Journal of Surgery 2005; 92: 24-32.

64. Yu WK, Chen YW, Shie HG, Lien TC, Kao HK, Wang JH. Hyperbaric oxygen therapy as an adjunctive treatment for sternal infection and osteomyelitis after sternotomy and cardiothoracic surgery. J Cardiothorac Surg 2011; 6: 141.

65. Shields RC, Nichols FC, Buchta WG, Claus PL. Hyperbaric oxygen therapy for chronic refractory osteomyelitis of the sternum. Ann Thorac Surg 2010; 89: 1661-3.

66. Barili F, Polvani G, Topkara VK, Dainese L, Cheema FH, Roberto M, et al. Role of hyperbaric oxygen therapy in the treatment of postoperative organ/space sternal surgical site infections. World J Surg 2007; 31: 1702-6.

67. Mills C, Bryson P. The role of hyperbaric oxygen in the treatment of sternal wound infection. Eur J Cardiothorac Surg 2006; 30: 153-9.

68. Pasquier D, Schmutz J, Lartigau E. Radio-induced lesion in normal tissues. Mathieu D, editor. Handbook on Hyperbaric Medicine. Dordrecht: Springer International Publishing; 2006.p.363-400.

69. Marx RE. Disorders approved for treatment with hyperbaric oxygen- Radiation injury to tissue. Kindwall EP, editor. Hyperbaric Medicine Practice. Arizona: Best Publishing Company; 1995.p.447-504.

70. Feldmeier JJ. Principles of wound management, Poblem wounds: the irradiated wound. Sheffield PL, Smith APS, Fife C, editors. Wound Care Practice. Arizona: Best Publishing Company; 2004.p.369-88.

71. Marx RE, Johnson RP, Kline SN. Prevention of osteoradionecrosis: a randomized prospective clinical trial of hyperbaric oxygen versus penicillin. JADA 1985; 111: 49-54.
72. Junior LHF, Limirio PHJO, Soares PBF, Dechichi P, De Souza Castro Filice L, Quagliatto PS, et al. The effect of hyperbaric oxygen therapy on bone macroscopy, composition and biomechanical properties after ionizing radiation injury. Radiat Oncol 2020; 15: 95.

73. Weinberger A, Siekmann U. Acute ischemic ophthalmological disorders. Mathieu D, editor. Handbook on Hyperbaric Medicine. Dordrecht: Springer International Publishing; 2006.p.527-36.

74. Beiran I, Goldberg I, Adir Y, Tamir A, Shupak A, Miller B. Early hyperbaric oxygen therapy for retinal artery occlusion. Eur J Ophtalmol 2001; 11: 345-50.

75. Bagli BS. Clinical efficiancy of hyperbaric oxygen therapy on idiopathic sudden sensorineural hearing loss. Undersea Hyperb Med 2020; 47: 51-6.

76. Bayoumy AB, De Ru JA. The use of hyperbaric oxygen in acute hearing loss: a narrative review. Eur Arch of Otorhinolaryngol 2019; 276: 1859-80.

77. Körpinar S, Alkan Z, Yiğit O, Gör AP, Toklu AS, Cakir B, et al. Factors influencing the outcome of idiopathic sudden sensorineural hearing loss treated with hyperbaric oxygen therapy. Eur Arch Otorhinolaryngol 2011; 268: 41-7.

78. Barthelemy A, Rocco M. Sudden deafness. Mathieu D, editor. Handbook on Hyperbaric Medicine. Dordrecht: Springer International Publishing; 2006.p.451-68.

79. Amaro CE, Espiney R, Radu L, Guerreiro F. Malignant (necrotizing) externa otitis: the experience of a single hyperbaric centre. Eur Arch Otorhinolaryngol 2019; 276: 1881-7.

80. Lampl L, Frey G. Intra-cranial abscess. Mathieu D, editor. Handbook on Hyperbaric Medicine. Dordrecht: Springer International Publishing; 2006.p.291-304.

81. Kutlay M, Colak A, Yıldız S, Demircan N, Akın ON. Stereotactic aspiration and antibiotic treatment combined with hyperbaric oxygen therapy in the management of bacterial brain abscesses. Neurosurgery 2008; 2: 540-6. 